\title{
Risk factors associated with asymptomatic infection by Leishmania chagasi in north-east Brazil
}

\author{
A. J. M. Caldas ${ }^{1}$, J. M. L. Costa ${ }^{1}$, A. A. M. Silva ${ }^{2}$, V. Vinhas ${ }^{3}$ and A. Barral ${ }^{3,4} \quad{ }^{1}$ Nucleus of Tropical Pathology \\ and Social Medicine, Federal University of Maranhão, ${ }^{2}$ Public Health Department, Federal University of Maranhão, \\ ${ }^{3}$ Immunology Service, Federal University of Bahia School of Medicine, ${ }^{4}$ Gonçalo Moniz Research Gentre, FIOCRUZ, Bahia, \\ Brazil
}

\begin{abstract}
Various factors have been associated with a predisposition to the development of clinical American visceral leishmaniasis (AVL). However, little information is available about the factors that predispose to asymptomatic infection. To identify the risk factors associated with asymptomatic infection, a study was carried out between July 1997 and June 1998 on children aged $0-5$ years in the districts of Vila Nova and Bom Viver in the municipality of Raposa in the island of São Luís, State of Maranhão, Brazil. A questionnaire containing socioeconomic, demographic and epidemiological data was used. The delayedtype hypersensitivity (DTH) test was carried out on 639 children in the first phase, and on 572 in the second, 7 months after the first survey, using Leishmania amazonensis antigen. Infection was determined by enzyme-linked immunosorbent assay (ELISA) in 638 children during the first phase, and in 572 during the second. Six outcome measures were used: initial prevalence, final prevalence and incidence, cach determined by DTH and ELISA. The incidence of infection was $10.8 \%$ when determined by DTH and $28.5 \%$ when determined by ELISA. After adjustment for confounding variables using Cox regression, infection by $L$. chagasi was associated with child's age ( $\geqslant 2$ years), location of the dwellings (Vila Nova) and reporting of relatives with AVL. Bathing outside the house and playing outdoors between 18:00 and 20:00 were identified as risk factors in some analyses but not in others. Presence of intra- and peridomestic Lutzomyia sandflies and animals such as dogs or chickens in the house or in the neighbourhood appeared as risk factors in some analyses but in others they unexpectedly seemed to protect from infection. Malnutrition was not found to be associated with infection.
\end{abstract}

Keywords: visceral leishmaniasis, Leishmania chagasi, asymptomatic infection, children, prevalence, incidence, risk factors, Brazil

\section{Introduction}

American visceral leishmaniasis (AVL) is an infectious disease causing significant immunological changes that lead to alterations in both cellular and humoral immunity. Of these, alterations in humoral immunity have been used as a criterion for diagnosis of the infection owing to the presence of elevated titres of specific antibodies (BADARó et al., 1986a; WHO, 1990; FNS, 1996).

AVL is caused by the parasite Leishmania chagasi and is transmitted by the bite of a Lutzomyia sandfly. It has been recently determined that large numbers of individuals in endemic areas are infected with the parasite but do not develop the classical signs and symptoms of the disease. A recent advance in our ability to identify persons in this group has been the development of a Leishmania-specific antibody test and skin test for the detection of leishmanial infection (BADARó et al., 1986b; REED et al., 1986).

An enzyme-linked immunosorbent assay (ELISA) has been used in both Brazil and Kenya to monitor asymptomatic and subclinical disease in addition to diagnosing acute AVL, and epidemiological studies have shown that the ratio of infected people, either asymptomatic or with subclinical disease, to those with classical symptoms of AVL ranges from 4 to $30: 1$ (BADARÓ et al., 1986a; JAHN et al., 1986; EVANS et al., 1992).

In endemic areas of north-east Brazil, it is estimated that $7.5 \%$ of individuals aged $<15$ years are infected by Leishmania each year, and about $20 \%$ of those infected by $L$. chagasi develop the classical form of the disease (BADARÓ et al., 1986a; WHO, 1990). The highest prevalence of human AVL occurs in children aged 0-9 years, who account for $80 \%$ of cases; of these, $60 \%$ are aged $<5$ years (BADARó et al., 1986a).

Various factors have been associated with a predis-

Address for correspondence: Arlene Caldas, Nucleo de Patologia Tropical e Medicina Social do Departamento de Patologia da Universidade Federal do Maranhão, Praça Madre Deus, $\mathrm{N}^{\circ} 2$, Madre Deus, 65.025-560, São Luis Maranhão, Brazil; fax +55 98 2225135, e-mail npatufma@elo.com.br position to the development of AVL disease, such as young age, malnutrition (BADARÓ et al., 1986a; CERF et al., 1987), poor lymphocyte proliferation, low production of gamma interferon (CARVALHO et al., 1992, 1994), and exposure to $L$. chagasi. However, little information is available about the factors that predispose to asymptomatic infection. According to Evans et al. (1992), the factors that determine the development of infection after transmission of $L$. chagasi by Lutzomyia sandflies have not been completely clarified. The island of São Luís in Maranhão is currently experiencing an epidemic of AVL, accounting for $65 \%$ of the total cases for the state (FNS, 1996). To identify possible risk factors that may lead to asymptomatic infection by $L$. chagasi after exposure, the delayed-type hypersensitivity (DTH) and ELISA tests were used in a population of north-east Brazil.

\section{Subjects and Methods}

A prospective study was carried out between July 1997 and June 1998 on all children aged $0-5$ years in the localities of Vila Nova and Bom Viver in the municipality of Raposa, Maranhão.

\section{Description of the area}

The island of São Luís has an area of $905 \mathrm{~km}^{2}$ and contains the municipalities of São Luís, São José de Ribamar, Paço do Lumiar and Raposa. The municipality of Raposa is situated $28 \mathrm{~km}$ from the city of São Luis, the state capital of Maranhão. The area of the municipality is $63.9 \mathrm{~km}^{2}$ and the population consists of 15075 inhabitants distributed among 21 districts, including Vila Nova and Bom Viver, the focus of the present study. The districts of Vila Nova and Bom Viver originated from recent land occupations, with respective populations of 2600 and 4307 inhabitants. The economic activity of the 2 localities is based on fishing and crafts. These localities were selected because they are endemic for AVL and have poor populations with little information concerning the disease (GAMA et al., 1997). In the past 3 years, the incidence of AVL observed in children aged $0-5$ years has varied in these districts: 22.8 cases per 1000 children in 1995 , 
9.4 cases per 1000 children in 1996 and 13.3 cases per 1000 children in 1997 (unpublished data obtained from the National Health Foundation).

\section{Study design}

The study was started in July 1997 with a population survey and then divided into 2 phases. The first (September-October 1997) involved a cross-sectional study using a standardized questionnaire applied to mothers/ guardians and examination by the study group during which children's height was measured and the DTH and ELISA tests were performed. In the second phase (April-May 1998) the DTH and ELISA tests, and height measurements, were repeated 7 months after the first phase.

The mothers/guardians gave written informed consent for the children to participate in the study. The wishes and decisions of the mothers were always respected.

In the choice of variables, associations found in other endemic areas were taken into account (BADARó et al. 1986c; CERF et al., 1987; EvANs et al., 1992). The variables contained in the questionnaire were: child's age (in months) and gender, father's and mother's literacy, type of housing, bathroom (indoors/outdoors), chronic malnutrition, place where the child plays in the early evening (indoors/outdoors), presence of animals (chickens, dogs or both), insecticide spraying during the previous year, AVL in relatives and neighbours, and Lutzomyia sandflies in the house.

\section{Description of measurements and tests}

The DTH was performed with $L$. amazonensis promastigotes (MHOMBR-88-BA-125) as previously described (REED et al., 1986). The test was applied intradermally to the anterior forearm, and readings were taken at 48-72 h after application (CUBA et al., 1985; WHO, 1990), with the diameter of the induration being measured with a millimetre ruler. One or both diameters of $\geqslant 5 \mathrm{~mm}$ was considered a positive reaction. The test was carried out on 639 children aged $0-71$ months in the first phase, and on 572 children aged 7-78 months in the second phase. The difference in the number of children between phases was due to migration occurring in these areas.

Antileishmanial antibodies were detected by ELISA using antigen prepared with $L$. chagasi in Bahia, Brazil. These antigens show high sensitivity $(98 \%)$ and specificity $(96 \%)$ for the detection of antibodies in sera from AVL patients (BADARó et al., 1986b). The test was performed on 638 children in the first phase and on 572 in the second. Eight children with hepatosplenomegaly and unexplained fever of more than 1 week's duration were considered to be potential cases of leishmaniasis, as confirmed with bone-marrow aspirate, and were excluded from the study. Blood $(2-4 \mathrm{~mL})$ was collected from each child, placed in tubes without heparin and left to coagulate at room temperature. The samples were then centrifuged and serum was separated. The serological reaction was considered positive when the level of absorbance (cut-off) was $\geqslant 0.045$, this figure representing 2 SD above the average absorbance level of a sample of 20 sera from healthy, non-exposed individuals.

Child's height was measured using a portable anthropometer and recorded to the last $0 \cdot 1 \mathrm{~cm}$. Children younger than 2 years were measured in the supine position and the others in the upright position. Data regarding the nutritional status of the children were analysed using the National Center for Health Statistics (NCHS) standards. Z-scores for height-for-age were calculated using the EpiInfo EpiNut software. Chronic malnutrition (stunting) was assessed by height-for-age $Z$ scores compared to the reference standards (WATERLOW, 1972; WATERLOW et al., 1977; WHO, 1986).

\section{Statistical analysis}

Unadjusted and adjusted relative risks (RRs) for initial prevalence, final prevalence and incidence of infection detected by DTH and ELISA were calculated with $95 \%$ confidence interval. The variables were classified into 2 or more categories, always taking the first category or that with the least risk as the baseline. Initial prevalence was defined as children with positive results in the first phase and final prevalence as children with positive results in the second. Incidence was calculated from the number of children with a negative result in the first phase and a positive result in the second phase, i.e., the number of children infected during the study period divided by the total number in the exposed population.

All variables presented in the unadjusted analysis were included in the multivariate analysis. A backward stepwise procedure was used with a $P$-value of 0.10 for retaining a variable in the final model. The results were adjusted for confounders by the Cox regression (Cox, 1972) technique using the STATA (1997) program, modified for sectional design (LEE, 1994), considering 7 months as the follow-up time for all children, with no removals from the study or losses to follow-up. Because the standard errors of the coefficients tend to be overestimated when Cox regression is applied to sectional designs, the robust method of calculating the variancecovariance matrix (IIN \& HEI, 1989) was used instead of the conventional inverse-matrix-of-second-derivatives method. In the calculation of the standard errors of the coefficients, we also took clustering into account because on some occasions more than 1 child per household participated in the study.

\section{Results}

Vila Nova consisted of 361 families and Bom Viver of 574 families. Each family had on average 5.9 persons and 3.9 children. Family income was lower than 1 Brazilian minimum wage in most cases $(89 \%)$ and almost all children have lived in the 2 districts since birth: $48 \%$ were males and $52 \%$ females. The incidence of $L$. chagasi infection was $10.8 \%$ when determined by DTH and $28.5 \%$ when determined by ELISA

\section{Unadjusted analysis of infection}

Regarding initial prevalence measured by $\mathrm{DTH}$, children aged 24-71 months, who used to bathe outside in the backyard and who had relatives with AVL were at increased risk of acquiring AVL infection. According to the ELISA test, children who lived in Vila Nova and who had relatives with AVL were at higher risk for AVI infection. The presence of chickens around the house or in the neighbourhood appeared to protect them from infection (Table 1).

Using tinal prevalence as the outcome, according to the DTH test, children aged $48-78$ months who lived in Vila Nova district were at higher risk for infection. Reporting Lutzomyia sandflies in the house, AVL in relatives and the presence of chickens or dogs in or around the house were associated with increased risk of infection. As measured by the ELISA test, only 3 risk factors were detected: age, playing in the backyard, and district of residence. Presence of Lutzomyia sandflies and dogs in the house appeared as protective factors (Table 2).

In terms of incidence of asymptomatic infection measured by DTH, children who lived in Vila Nova district and who reported Lutzomyia sandflies or dogs in the house/neighbourhood or AVL in relatives were at increased risk of infection. According to ELISA, child's age, playing around the house between 18:00 and 20:00 and residence in Vila Nova district were associated with infection (Table 3 ).

The male sex was not found to be a risk factor of infection. The houses in Bom Viver were in better conditions than those in Vila Nova. However, living in 
Table 1. Unadjusted analysis of the initial prevalence of asymptomatic $L$. chagasi infection measured by DTH and ELISA (Raposa-Maranhão, Brazil, 1997)

\begin{tabular}{|c|c|c|c|c|c|c|c|c|}
\hline \multirow[b]{2}{*}{ Variable } & \multicolumn{4}{|c|}{ DTH $(n=639)$} & \multicolumn{4}{|c|}{ ELISA $(n=638)$} \\
\hline & $n$ & $\begin{array}{l}\text { Positive } \\
(\%)\end{array}$ & $\mathrm{RR}(95 \% \mathrm{CI})$ & $P$ & $n$ & $\begin{array}{l}\text { Positive } \\
(\%)\end{array}$ & RR $(95 \% \mathrm{CI})$ & $P$ \\
\hline Age (months) & & & & 0.027 & & & & 0.500 \\
\hline $0-23$ & 231 & 13 & $1 \cdot 00$ & & 227 & 12 & $1 \cdot 00$ & \\
\hline $24-47$ & 225 & 21 & $1.64(1.08-2.49)$ & & 226 & 14 & $1.24(0.76-2.01)$ & \\
\hline $48-71$ & 183 & 22 & $1.73(1.13-2 \cdot 64)$ & & 185 & 15 & $1.32(0.81-2.14)$ & \\
\hline Gender & & & & 0.665 & & & & 0.605 \\
\hline Female & 334 & 18 & $1 \cdot 00$ & & 332 & 14 & $1 \cdot 00$ & \\
\hline Male & 305 & 19 & $1.08(0.77-1.51)$ & & 306 & 13 & $0.90(0.60-1.34)$ & \\
\hline Chronic malnutrition & & & & 0.970 & & & & $0 \cdot 752$ \\
\hline No & 477 & 19 & 1.00 & & 480 & 14 & $1 \cdot 00$ & \\
\hline Yes & 162 & 19 & $0.99(0.67-1.47)$ & & 158 & 13 & $0.92(0.55-1.54)$ & \\
\hline Play & & & & 0.915 & & & & 0.295 \\
\hline Indoors & 587 & 19 & $1 \cdot 00$ & & 590 & 13 & 1.00 & \\
\hline Outdoors & 52 & 19 & $1.04(0.54-1.97)$ & & 48 & 19 & $1 \cdot 44(0.73-2 \cdot 83)$ & \\
\hline Bathing place & & & & 0.002 & & & & 0.406 \\
\hline Indoors & 111 & 7 & 1.00 & & 111 & 16 & $1 \cdot 00$ & \\
\hline Outdoors & 528 & 21 & $2 \cdot 92(1 \cdot 46-5 \cdot 82)$ & & 527 & 13 & $0.80(0.46-1.36)$ & \\
\hline Father's literacy & & & & 0.279 & & & & 0.909 \\
\hline Can read and write & 350 & 20 & $1 \cdot 00$ & & 352 & 14 & $1 \cdot 00$ & \\
\hline $\begin{array}{l}\text { Cannot read or } \\
\text { write }\end{array}$ & 289 & 17 & $0.82(0.57-1 \cdot 18)$ & & 286 & 13 & $0.97(0.62-1.52)$ & \\
\hline Mother's literacy & & & & 0.921 & & & & 0.438 \\
\hline Can read and write & 443 & 19 & $1 \cdot 00$ & & 442 & 14 & $1 \cdot 00$ & \\
\hline $\begin{array}{l}\text { Cannot read or } \\
\text { write }\end{array}$ & 196 & 18 & $0.98(0.66-1.45)$ & & 196 & 12 & $0.82(0.50-1.35)$ & \\
\hline Districts & & & & $0 \cdot 148$ & & & & $<0.001$ \\
\hline Bom Viver & 348 & 16 & 1.00 & & 348 & 7 & $1 \cdot 00$ & \\
\hline Vila Nova & 291 & 21 & $1.30(0.91-1.86)$ & & 290 & 22 & $3 \cdot 29(1 \cdot 94-5 \cdot 56)$ & \\
\hline Type of housing & & & & $0 \cdot 141$ & & & & 0.427 \\
\hline $\begin{array}{l}\text { Bricks/tiles/ } \\
\text { cement/ceramic }\end{array}$ & 55 & 11 & $1 \cdot 00$ & & 57 & 9 & $1 \cdot 00$ & \\
\hline $\begin{array}{l}\text { Mud walls/straw/ } \\
\text { earthen }\end{array}$ & 584 & 19 & $1.77(0.83-3.80)$ & & 581 & 14 & $1.59(0.51-4.98)$ & \\
\hline $\begin{array}{l}\text { Lutzomyia sandflies } \\
\text { in house }\end{array}$ & & & & 0.603 & & & & 0.413 \\
\hline No & 219 & 17 & $1 \cdot 00$ & & 220 & 12 & $1 \cdot 00$ & \\
\hline Yes & 420 & 19 & $1 \cdot 11(0 \cdot 75-1.66)$ & & 418 & 14 & $1.21(0.76-1.94)$ & \\
\hline Spraying last year & & & & $0 \cdot 205$ & & & & 0.629 \\
\hline Yes & 536 & 20 & 1.00 & & 537 & 14 & $1 \cdot 00$ & \\
\hline No & 103 & 14 & $0.69(0.39-1.22)$ & & 101 & 12 & $0.86(0.47-1.57)$ & \\
\hline $\begin{array}{l}\text { Animals in house/ } \\
\text { neighbourhood }\end{array}$ & & & & $0 \cdot 804$ & & & & $0 \cdot 011$ \\
\hline None & 249 & 20 & 1.00 & & 253 & 16 & $1 \cdot 00$ & \\
\hline Chickens & 181 & 17 & $0.87(0.56-1.36)$ & & 180 & 7 & $0.42(0.21-0.83)$ & \\
\hline Dogs & 121 & 21 & $1.05(0.65-1.69)$ & & 119 & 21 & $1.33(0.80-2 \cdot 21)$ & \\
\hline Chickens and dogs & 88 & 16 & $0.81(0.44-1.49)$ & & 86 & 11 & $0.66(0.31-1.40)$ & \\
\hline AVL in relatives & & & & 0.019 & & & & $0 \cdot 014$ \\
\hline No & 618 & 18 & 1.00 & & 618 & 13 & $1 \cdot 00$ & \\
\hline Yes & 21 & 38 & $2 \cdot 12(1 \cdot 13-3 \cdot 98)$ & & 20 & 30 & $2 \cdot 32(1 \cdot 18-4 \cdot 54)$ & \\
\hline AVL in neighbours & & & & 0.794 & & & & 0.913 \\
\hline No & 610 & 19 & $1 \cdot 00$ & & 610 & 13 & $1 \cdot 00$ & \\
\hline Yes & 29 & 21 & $1.12(0.49-2.56)$ & & 28 & 14 & $1.06(0.36-3.16)$ & \\
\hline
\end{tabular}

DTH, delayed type hypersensitivity skin test with $L$. amazonensis antigen; ELISA, enzyme-linked immunosorbent assay for serum antibodies against $L$. chagasi antigen; RR ( $95 \% \mathrm{CI})$, relative risk ( $95 \%$ confidence interval); AVL, American visceral leishmaniasis.

a mud house with a straw roof and an earthen floor was not a risk factor for infection.

With respect to parental literacy, $31 \%$ of mothers and $46 \%$ of fathers did not know how to read or write. Nevertheless, illiteracy was not shown to be associated with increased risk of infection. The prevalence of chronic malnutrition among the children in the 2 phases of the study was high $(25.5 \%$ and $26.0 \%$, respectively), but this was not shown to be a risk factor in either analysis.

Adjusted analysis of infection

Using initial prevalence as the outcome, bathing out- side the house and reporting AVL cases in relatives were risk factors for infection as measured by DTH. In addition, children who lived in Vila Nova district had a higher risk of infection according to ELISA, whereas the presence of chickens in the house or in the neighhourhood seemed to protect them from infection (Table 4). Regarding final prevalence as measured by DTH, child's age, residence in Vila Nova district, reporting AVL in relatives, presence of chickens or dogs in the house or in the neighbourhood and reporting the presence of Lutzomyia sandflies in the house were associated with increased risk of infection. When ELISA tests were considered, playing outdoors was also 
Table 2. Unadjusted analysis of the final prevalence of asymptomatic $L$. chagasi infection measured by DTH and ELISA (Raposa-Maranhão, Brazil, 1998)

\begin{tabular}{|c|c|c|c|c|c|c|c|c|}
\hline \multirow[b]{2}{*}{ Variable } & \multicolumn{4}{|c|}{$\mathrm{DTH}(n=572)$} & \multicolumn{4}{|c|}{ ELISA $(n=572)$} \\
\hline & $n$ & $\begin{array}{c}\text { Positive } \\
(\%)\end{array}$ & $\operatorname{RR}(95 \% \mathrm{CI})$ & $P$ & $n$ & $\begin{array}{l}\text { Positive } \\
(\%)\end{array}$ & RR $(95 \% \mathrm{CI})$ & $P$ \\
\hline Age (months) & & & & $0 \cdot 270$ & & & & $<0.001$ \\
\hline $0-23$ & 137 & 13 & $1 \cdot 00$ & & 137 & 21 & $1 \cdot 00$ & \\
\hline $24-47$ & 214 & 20 & $1.53(0.94-2.49)$ & & 214 & 33 & $1 \cdot 57(1 \cdot 10-2 \cdot 24)$ & \\
\hline $48-78$ & 221 & 25 & $1.93(1 \cdot 19-3 \cdot 13)$ & & 221 & 44 & $2 \cdot 07(1 \cdot 46-2 \cdot 95)$ & \\
\hline Sex & & & & $0 \cdot 989$ & & & & $0 \cdot 165$ \\
\hline Female & 293 & 20 & $1 \cdot 00$ & & 293 & 37 & $1 \cdot 00$ & \\
\hline Male & 279 & 20 & $1.00(0.72-1 \cdot 38)$ & & 279 & 32 & $0.85(0.67-1.07)$ & \\
\hline Chronic malnutrition & & & & $0 \cdot 273$ & & & & $0 \cdot 876$ \\
\hline No & 410 & 19 & $1 \cdot 00$ & & 410 & 35 & $1 \cdot 00$ & \\
\hline Yes & 162 & 24 & $1.22(0.86-1 \cdot 73)$ & & 162 & 34 & $0.98(0.76-1.26)$ & \\
\hline Play & & & & $0 \cdot 718$ & & & & $<0.001$ \\
\hline Indoors & 523 & 21 & $1 \cdot 00$ & & 523 & 32 & $1 \cdot 00$ & \\
\hline Outdoors & 49 & 18 & $0.89(0.47-1.68)$ & & 49 & 59 & $1 \cdot 84(1 \cdot 41-2 \cdot 40)$ & \\
\hline Bathing place & & & & 0.502 & & & & $0 \cdot 170$ \\
\hline Indoors & 100 & 18 & $1 \cdot 00$ & & 100 & 28 & $1 \cdot 00$ & \\
\hline Outdoors & 472 & 21 & $1 \cdot 17(0.75-1.82)$ & & 472 & 36 & $1.28(0.90-1.82)$ & \\
\hline Father's literacy & & & & $0 \cdot 342$ & & & & $0 \cdot 411$ \\
\hline Can read and write & 307 & 19 & $1 \cdot 00$ & & 307 & 33 & $1 \cdot 00$ & \\
\hline $\begin{array}{l}\text { Cannot read or } \\
\text { write }\end{array}$ & 265 & 22 & $1 \cdot 18(0 \cdot 84-1 \cdot 65)$ & & 265 & 36 & $1 \cdot 10(0 \cdot 88-1 \cdot 39)$ & \\
\hline Mother's literacy & & & & $0 \cdot 832$ & & & & $0 \cdot 147$ \\
\hline Can read and write & 391 & 20 & $1 \cdot 00$ & & 391 & 32 & $1 \cdot 00$ & \\
\hline $\begin{array}{l}\text { Cannot read or } \\
\text { write }\end{array}$ & 181 & 21 & $1 \cdot 04(0 \cdot 73-1 \cdot 48)$ & & 181 & 39 & $1 \cdot 19(0 \cdot 94-1 \cdot 51)$ & \\
\hline Districts & & & & $<0.001$ & & & & $<0.001$ \\
\hline Bom Viver & 312 & 14 & $1 \cdot 00$ & & 312 & 28 & $1 \cdot 00$ & \\
\hline Vila Nova & 260 & 29 & $2 \cdot 07(1.44-2 \cdot 96)$ & & 260 & 43 & $1.55(1.23-1.96)$ & \\
\hline Type of housing & & & & 0.052 & & & & $0 \cdot 784$ \\
\hline $\begin{array}{l}\text { Bricks/tiles/ } \\
\text { cement/ceramic }\end{array}$ & 52 & 10 & $1 \cdot 00$ & & 52 & 33 & $1 \cdot 00$ & \\
\hline $\begin{array}{l}\text { Mud walls/straw/ } \\
\text { earthen }\end{array}$ & 520 & 22 & $2 \cdot 24(0 \cdot 99-5 \cdot 04)$ & & 520 & 35 & $1.06(0.70-1.59)$ & \\
\hline $\begin{array}{l}\text { Lutzomyia sandflies } \\
\text { in house }\end{array}$ & & & & 0.005 & & & & 0.012 \\
\hline No & 190 & 13 & 1.00 & & 190 & 42 & 1.00 & \\
\hline Yes & 382 & 24 & $1 \cdot 83(1 \cdot 21-2 \cdot 78)$ & & 382 & 31 & $0.74(0.59-0.94)$ & \\
\hline Spraying last year & & & & $0 \cdot 293$ & & & & 0.096 \\
\hline Ycs & 479 & 21 & 1.00 & & 479 & 33 & 1.00 & \\
\hline No & 93 & 16 & $0.76(0.45-1.27)$ & & 93 & 42 & $1.27(0.96-1.69)$ & \\
\hline Animals in house/ & & & & $0 \cdot 004$ & & & & $0 \cdot 087$ \\
\hline None & 218 & 15 & 1.00 & & 218 & 38 & $1 \cdot 00$ & \\
\hline Chickens & 164 & 23 & $1.54(0.99-2.39)$ & & 164 & 34 & $0.89(0.67-1.18)$ & \\
\hline Dogs & 106 & 32 & $2 \cdot 19(1 \cdot 41-3 \cdot 39)$ & & 106 & 25 & $0.65(0.45-0.95)$ & \\
\hline Chickens and dogs & 84 & 17 & $1 \cdot 14(0.62-2 \cdot 08)$ & & 84 & 41 & $1.08(0.80-1.45)$ & \\
\hline AVL in relatives & & & & $<0.001$ & & & & 0.594 \\
\hline No & 552 & 19 & $1 \cdot 00$ & & 552 & 34 & 1.00 & \\
\hline Yes & 20 & 60 & $3 \cdot 15(1.99-5 \cdot 00)$ & & 20 & 40 & $1 \cdot 17(0 \cdot 66-2 \cdot 07)$ & \\
\hline AVL in neighbours & & & & $0 \cdot 547$ & & & & $0 \cdot 734$ \\
\hline No & 545 & 20 & 1.00 & & 545 & 34 & 1.00 & \\
\hline Yes & 27 & 26 & $1 \cdot 28(0 \cdot 57-2 \cdot 90)$ & & 27 & 37 & $1.08(0.69-1.68)$ & \\
\hline
\end{tabular}

For explanation of the abbreviations, see the footnote to Table 1.

identified as a risk factor for infection. In contrast to DTH results, the presence of dogs and Lutzomyia sandflies in the house appeared to confer protection against $L$. chagasi infection according to the ELISA test.

Using incidence as a measure of infection, according to $\mathrm{DTH}$, residence in Vila Nova district, presence of dogs in the house or in the neighbourhood and reporting AVL in relatives conferred a higher risk of infection. By the ELISA test, children aged 24-48 months who played outside the house between 18:00 and 20:00 and lived in Vila Nova district were at increased risk for infection. In contrast, presence of Lutzomyia sandflies in the house appeared to protect children from infection (Table 4).

\section{Discussion}

In this study, 6 outcome measures were used. The variables that were most relevant and may thus predict the risk of asymptomatic infection by $L$. chagasi were district of residence, reporting AVL in relatives and child's age. Some variables appear to increase the risk of infection in some analyses but not in others, as was the case for playing outdoors in the early evening. Use of an outdoor bathroom predicted infection only once.

Presence of Lutzomyia sandflies in the house was 
Table 3. Unadjusted analysis of the incidence of asymptomatic $L$. chagasi infection measured by DTH and ELISA (Raposa-Maranhão, Brazil, 1998)

\begin{tabular}{|c|c|c|c|c|c|c|c|c|}
\hline \multirow[b]{2}{*}{ Variable } & \multicolumn{4}{|c|}{ DTH $(n=469)$} & \multicolumn{4}{|c|}{ ELISA $(n=485)$} \\
\hline & $n$ & $\begin{array}{l}\text { Positive } \\
(\%)\end{array}$ & $\mathrm{RR}(95 \% \mathrm{CI})$ & $P$ & $n$ & $\begin{array}{l}\text { Positive } \\
(\%)\end{array}$ & RR (95\% CI) & $P$ \\
\hline Age (months) & & & & $0 \cdot 194$ & & & & $<0.001$ \\
\hline $0-23$ & 123 & 11 & $1 \cdot 00$ & & 118 & 19 & $1 \cdot 00$ & \\
\hline $24-47$ & 169 & 11 & $0.94(0.50-1.74)$ & & 184 & 31 & $1.66(1.09-2.52)$ & \\
\hline $48-78$ & 177 & 17 & $1.49(0.82-2.71)$ & & 183 & 44 & $2.37(1.58-3.57)$ & \\
\hline Sex & & & & 0.710 & & & & 0.367 \\
\hline Female & 245 & 13 & $1 \cdot 00$ & & 246 & 35 & $1 \cdot 00$ & \\
\hline Male & 224 & 14 & $1.09(0.68-1.75)$ & & 239 & 31 & $0.89(0.68-1.15)$ & \\
\hline Chronic malnutrition & & & & 0.869 & & & & 0.590 \\
\hline $\begin{array}{l}\text { No } \\
\text { Yes }\end{array}$ & 337 & 13 & $1 \cdot 00$ & & 347 & 34 & 1.00 & \\
\hline Yes & 132 & 14 & $1.04(0.62-1.75)$ & & 138 & 31 & $0.92(0.69-1.23)$ & \\
\hline Play & & & & $0 \cdot 147$ & & & & 0.001 \\
\hline Indoors & 429 & 14 & $1 \cdot 00$ & & 448 & 31 & $1 \cdot 00$ & \\
\hline Outdoors & 40 & 5 & $0.36(0.09-1.44)$ & & 37 & 54 & $1 \cdot 73(1 \cdot 24-2 \cdot 41)$ & \\
\hline Bathing place & & & & 0.955 & & & & 0.059 \\
\hline Indoors & 92 & 13 & $1 \cdot 00$ & & 82 & 23 & $1 \cdot 00$ & \\
\hline Outdoors & $37 \overline{7}$ & 13 & $1 \cdot 02(0.57-1 \cdot 82)$ & & 403 & 35 & $1.51(0.98-2 \cdot 32)$ & \\
\hline Father's literacy & & & & $0 \cdot 144$ & & & & $0 \cdot 196$ \\
\hline Can read and write & 247 & 11 & $1 \cdot 00$ & & 260 & 31 & 1.00 & \\
\hline $\begin{array}{l}\text { Cannot read or } \\
\text { write }\end{array}$ & 222 & 16 & $1 \cdot 44(0 \cdot 88-2 \cdot 36)$ & & 225 & 36 & $1.18(0.92-1.53)$ & \\
\hline Mother's literacy & & & & 0.370 & & & & $0 \cdot 117$ \\
\hline Can read and write & 319 & 12 & $1 \cdot 00$ & & 329 & 31 & $1 \cdot 00$ & \\
\hline $\begin{array}{l}\text { Cannot read or } \\
\text { write }\end{array}$ & 150 & 15 & $1 \cdot 25(0 \cdot 76-2 \cdot 06)$ & & 156 & 38 & $1.23(0.95-1.60)$ & \\
\hline Districts & & & & $<0.001$ & & & & 0.001 \\
\hline Bom viver & 263 & 7 & $1 \cdot 00$ & & 287 & 27 & $1 \cdot 00$ & \\
\hline Vila Nova & 206 & 21 & $3 \cdot 12(1 \cdot 79-5 \cdot 45)$ & & 198 & 41 & $1.52(1.18-1.97)$ & \\
\hline Type of housing & & & & 0.054 & & & & 0.419 \\
\hline $\begin{array}{l}\text { Bricks/tiles/ } \\
\text { cement/ceramic }\end{array}$ & 46 & 2 & $1 \cdot 00$ & & 47 & 28 & $1 \cdot 00$ & \\
\hline $\begin{array}{l}\text { Mud walls/straw/ } \\
\text { earthen }\end{array}$ & 423 & 14 & $6.63(0.97-45.59)$ & & 438 & 34 & $1 \cdot 21(0 \cdot 76-1 \cdot 94)$ & \\
\hline $\begin{array}{l}\text { Lutzomyia sandflies } \\
\text { in house }\end{array}$ & & & & 0.028 & & & & 0.069 \\
\hline No & 159 & 8 & 1.00 & & 164 & 38 & $1 \cdot 00$ & \\
\hline Yes & 310 & 16 & $1.93(1.07-3.48)$ & & 321 & 30 & $0.79(0.61-1.02)$ & \\
\hline Spraying last year & & & & 0.924 & & & & $0 \cdot 157$ \\
\hline Yes & 388 & 13 & $1 \cdot 00$ & & 407 & 32 & $1 \cdot 00$ & \\
\hline No & 81 & 14 & $1.03(0.53-2.02)$ & & 78 & 40 & $1.25(0.92-1.72)$ & \\
\hline $\begin{array}{l}\text { Animals in house/ } \\
\text { ncighbourhood }\end{array}$ & & & & 0.032 & & & & 0.636 \\
\hline None & 180 & 10 & $1 \cdot 00$ & & 181 & 35 & 1.00 & \\
\hline Chickens & 135 & 14 & $1.41(0.75-2.63)$ & & 150 & 33 & $0.94(0.69-1.28)$ & \\
\hline Dogs & 84 & 23 & $2 \cdot 26(1 \cdot 23-4 \cdot 17)$ & & 81 & 27 & $0.78(0.52-1.18)$ & \\
\hline Chickens and dogs & 70 & 9 & $0.86(0.35-2.08)$ & & 73 & 36 & $1.02(0.72-1.46)$ & \\
\hline AVL in relatives & & & & $0 \cdot 042$ & & & & $0 \cdot 889$ \\
\hline No & 457 & 13 & $1 \cdot 00$ & & 472 & 33 & $1 \cdot 00$ & \\
\hline Yes & 12 & 33 & $2 \cdot 63(1.04-6 \cdot 66)$ & & 13 & 31 & $0.93(0.34-2.54)$ & \\
\hline AVL in neighbours & & & & 0.963 & & & & 0.578 \\
\hline No & 447 & 13 & $1 \cdot 00$ & & 464 & 33 & $1 \cdot 00$ & \\
\hline Yes & 22 & 14 & $1 \cdot 03(0 \cdot 26-4 \cdot 15)$ & & 21 & 38 & $1.16(0.68-1.98)$ & \\
\hline
\end{tabular}

For explanation of the abbreviations, see the footnote to Table 1.

found to be a risk factor for infection in one analysis (final prevalence as measured by DTH), whereas in 2 other analyses it appeared to be protective, as was the case for final prevalence and incidence according to the ELISA test. Presence of animals in the house or in the neighbourhood showed the same behaviour. In 2 analyses (final prevalence and incidence according to DTH) the presence of dogs or chickens tended to increase the risk of asymptomatic infection. However, according to ELISA, presence of chickens appeared to protect children from infection in the case of initial prevalence and the presence of dogs seemed to decrease the risk of infection in the final prevalence analysis.
What may be the reasons for these inconsistencies between the 6 analyses? At first, 3 different endpoints of infection were used: initial prevalence, final prevalence and incidence. Asymptomatic infection was identified by 2 different tests: DTH and ELISA. These 2 tests measure different types of the immune response and thus are not likely to produce the same results. In the case of presence of Lutzomyia sandflies and animals in the house, DTH identified these variables as risk factors, whereas ELISA identified them as protective factors. Other reasons for this might be random error or confounding by other factors not accounted for in the analysis. In addition, past insecticide spraying and 
Table 4. Adjusted analysis of the initial prevalence, final prevalence and incidence of asymptomatic $L$. chagasi infection measured by DTH and ELISA (Raposa-Maranhão, Brazil, 1998)

\begin{tabular}{|c|c|c|c|c|}
\hline \multirow[b]{2}{*}{ Variable } & \multicolumn{2}{|l|}{ DTH } & \multicolumn{2}{|l|}{ ELISA } \\
\hline & $\mathrm{RR}(95 \% \mathrm{CI})$ & $P$ & $\mathrm{RR}(95 \% \mathrm{CI})$ & $P$ \\
\hline \multicolumn{5}{|l|}{ Initial prevalence } \\
\hline Bathing place & & 0.002 & & \\
\hline Indoors & $1 \cdot 00$ & & & \\
\hline $\begin{array}{l}\text { Outdoors } \\
\text { Districts }\end{array}$ & $2 \cdot 97(1 \cdot 49-5 \cdot 90)$ & & & \\
\hline $\begin{array}{l}\text { Districts } \\
\text { Bom Viver }\end{array}$ & & & 1.00 & $<0.001$ \\
\hline $\begin{array}{l}\text { Bom Viver } \\
\text { Vila Nova }\end{array}$ & & & $2 \cdot 98(1 \cdot 75-5 \cdot 07)$ & \\
\hline AVL in relatives & & 0.012 & & \\
\hline No & $1 \cdot 00$ & & & \\
\hline Yes & $2 \cdot 23(1 \cdot 19-4 \cdot 27)$ & & & \\
\hline Animals in house/neighbourhood & & & & 0.062 \\
\hline None & & & $1 \cdot 00$ & \\
\hline Chickens & & & $0.51(0.26-0.99)$ & \\
\hline Dogs & & & $1 \cdot 31(0 \cdot 80-2 \cdot 16)$ & \\
\hline Chickens and dogs & & & $0.75(0.37-1.53)$ & \\
\hline \multicolumn{5}{|l|}{ Final prevalence } \\
\hline Age (months) & & 0.053 & & $<0.001$ \\
\hline $0-23$ & 1.00 & & $1 \cdot 00$ & \\
\hline $24-47$ & $1.55(0.97-2.48)$ & & $1 \cdot 56(1 \cdot 10-2 \cdot 21)$ & \\
\hline $48-78$ & $1 \cdot 81(1 \cdot 12-2 \cdot 92)$ & & $2 \cdot 19(1.56-3 \cdot 05)$ & \\
\hline Play & & & & $<0.001$ \\
\hline Indoors & & & 1.00 & \\
\hline Outdoors & & & $1.69(1.29-2 \cdot 22)$ & \\
\hline Districts & & $<0.001$ & & $<0.001$ \\
\hline Bom Viver & 1.00 & & $1 \cdot 00$ & \\
\hline Vila Nova & $2 \cdot 02(1 \cdot 42-2 \cdot 87)$ & & $1 \cdot 58(1.26-1 \cdot 97)$ & \\
\hline AVL in relatives & & 0.008 & & \\
\hline No & 1.00 & & & \\
\hline Yes & $1 \cdot 98(1 \cdot 19-3 \cdot 29)$ & & & \\
\hline Animals in house/neighbourhood & & $0 \cdot 014$ & & 0.017 \\
\hline None & $1 \cdot 00$ & & 1.00 & \\
\hline Chickens & $1.65(1 \cdot 07-2 \cdot 54)$ & & $0.94(0.72-1.24)$ & \\
\hline Dogs & $1.98(1.29-3 \cdot 05)$ & & $0.64(0.44-0.91)$ & \\
\hline Chickens and dogs & $1 \cdot 26(0 \cdot 71-2 \cdot 22)$ & & $1 \cdot 19(0 \cdot 88-1 \cdot 60)$ & \\
\hline Lutzomyia sandflies in house & & $0 \cdot 019$ & & 0.009 \\
\hline No & 1.00 & & $1 \cdot 00$ & \\
\hline Yes & $1.65(1.08-2 \cdot 51)$ & & $0.75(0.60-0.93)$ & \\
\hline \multicolumn{5}{|l|}{ Incidence } \\
\hline Age (months) & & & & $<0.001$ \\
\hline $0-23$ & & & $1 \cdot 00$ & \\
\hline $24-47$ & & & $1 \cdot 66(1 \cdot 10-2 \cdot 51)$ & \\
\hline $48-78$ & & & $2 \cdot 38(1 \cdot 60-3 \cdot 56)$ & \\
\hline Play & & 0.076 & & $0 \cdot 015$ \\
\hline Indoors & $1 \cdot 00$ & & $1 \cdot 00$ & \\
\hline Outdoors & $0.26(0 \cdot 06-1 \cdot 15)$ & & $1 \cdot 51(1 \cdot 08-2 \cdot 10)$ & \\
\hline Districts & & $<0.001$ & & 0.001 \\
\hline Bom Viver & $1 \cdot 00$ & & 1.00 & \\
\hline Vila Nova & $3 \cdot 10(1 \cdot 77-5 \cdot 44)$ & & $1.52(1 \cdot 18-1 \cdot 95)$ & \\
\hline Lutzomyia sandflies in house & & & & 0.033 \\
\hline No & & & $1 \cdot 00$ & \\
\hline Yes & & & $0.77(0.60-0.98)$ & \\
\hline Animals in house/neighbourhood & & 0.027 & & \\
\hline None & $1 \cdot 00$ & & & \\
\hline Chickens & $1.67(0.88-3 \cdot 16)$ & & & \\
\hline Dogs & $2 \cdot 15(1 \cdot 21-3 \cdot 82)$ & & & \\
\hline Chickens and dogs & $0.92(0.40-2 \cdot 14)$ & & & \\
\hline AVL in relatives & & 0.034 & & \\
\hline No & $1 \cdot 00$ & & & \\
\hline Yes & $2 \cdot 61(1.08-6 \cdot 34)$ & & & \\
\hline
\end{tabular}

For explanation of the abbreviations, see the footnote to Table 1.

presence of Lutzomvia sandflies were determined using the questionnaire. Even though the 2 communities had been recently exposed to a comprehensive programme of health education regarding prevention of AVL, differential misclassification might have distorted some results. Residual confounding is another possibility due to this probable misclassification in the assessment of these 2 variables. However, if differential misclassification had affected the results it would have been expected to produce distortion in only one direction. This 
is not completely in agreement with what was observed, since presence of Lutzomyia sandflies was found to be a risk factor in some analyses but not in others. These inconsistencies are most probably linked to the type of test used to detect infection. Our results are in agreement with some reports that have revealed that DTH is more sensitive in detecting early infection whereas ELISA is more sensitive in identifying symptomatic infection (BADARó et al., 1986b; DYE et al., 1993; FNS, 1996). Underreporting of past spraying was more likely to have occurred and may have produced some degree of non-differential misclassification and a bias towards the null.

Children aged $\geqslant 2$ years had a higher relative risk for infection than those aged $<2$ years. This finding is consistent with those obtained by BADARó et al. (1986a) in Jacobina, Bahia, Brazil, where the frequency of infection rose after 1 year of age, and with those of PAMPIGLIONE et al. (1975) obtained in Mediterranean regions, and is also in agreement with observations by AII \& ASHFORD (1993) in Ethiopia. It is important to note that prevalence of infection tends to increase with age since there is little or no immunological recovery from infection as measured by DTH. However, recovery from ELISA may be significant. This may explain why age was not associated with infection when the outcome measure was initial prevalence, whereas it was associated with infection when final prevalence was considered. On this basis, variation in incidence with age is more elucidative and age was also associated with increased risk of infection as measured by ELISA.

It was also noted that Vila Nova children experienced a relative risk of infection 3 times greater than Bom Viver children. This difference was probably due to a more intense migratory process or to a higher Lutzomyia longipalpis density in Vila Nova than in Bom Viver. With increased migration, more susceptible individuals enter the area, some taking with them their infected dogs, and are at greater risk of becoming infected and presenting as new cases of the illness (Evans et al., 1992; FNS, 1996).

The study showed that living conditions in Vila Nova and Bom Viver are precarious. Studies carried out in the state of Para have shown that children living in areas of land occupations are at increased risk for AVL due to the large number of susceptible people settling in the area, increases in population density of $L u$. longipalpis and living conditions that may encourage the vector's entry, especially in the more open-built houses (SIlvEIRA et al., 1997). In our study, however, the type of dwelling did not represent a risk factor. The Lutzomyia sandfly is found throughout all of São Luis city (REBÊLO et al., 1996), including zones at the periphery of urban conglomerations. In Bom Viver it predominates over other species $(97 \%$ of all species captured were $L u$. longipalpis), and has as easy targets young children who tend to sleep wearing little or no clothing, leaving the body's surface exposed (ARAújo et al., 2000).

Reporting AVL in relatives was associated with infection, in agreement with PAMPIGLIONE et al. (1975) who detected a higher infection rate in those who had reported cases in relatives or in neighbours in Emilia Romagna and Sicily in the Mediterranean region. ABRAMSON et al. (1995) showed that infection among those who had experienced contact with AVL cases can suggest the occurrence of subclinical infections in many people in endemic areas.

It is known that transmission of AVL occurs through the bite of a Lutzomyia sandfly, and therefore in some analyses the presence of these insects in the peri- and intradomestic areas was a risk factor for infection by $L$. chagasi, as also was the presence of dogs and chickens. The presence of chickens circulating around the house may increase the population density of $I .1$. longipalpis. The domestication of the vector $L u$. longipalpis can be stimulated by factors such as recent urbanization with the derangement of the ecology, by the food sources of humans and animals (dogs, chickens), by abundant tree planting in backyards and by the accumulation of waste (WHO, 1990), characteristics that were common in the study area. The role of chickens in the epidemiology of AVL is a possibility raised by one of our analyses that remains open to debate. However, the lack of consistency of this association found in the present study argues against this possibility. Moderate or severe malnutrition was not found to be linked with infection either in the adjusted or non-adjusted cases for the 2 parameters used. BADARó et al. (1986a), while studying risk factors associated with AVL in Jacobina, Bahia, verified that in areas of highest incidence of the disease a 2 -year-old child had a 1 in 10 chance of being infected, and, if infected, a 1 in 4 chance of developing the disease. If a similar child suffered from malnutrition, the probability of developing the disease was $1: 2$. CERF et al. (1987) reported that children with severe or moderate malnutrition were exposed to an $8 \cdot 7$-fold risk of developing the disease.

Our data, compared to previous studies, illustrate that risk factors for visceral leishmaniasis may vary among different settings and populations. This observation is not unexpected in a disease with multiple risk factors. In such cases, the role of a single factor is dependent on the role played by other components. Studies in different areas will contribute to a clearer worldwide picture of the most relevant risk factors for visceral leishmaniasis. In addition, new research may contribute to the elucidation of the reasons for some unexpected associations found in this study.

\section{Acknowledgements}

This work was supported in part by grants AI-30639 from the National Institute of Health and PRONEX, Brazilian National Research Council (CNPq). A. Barral is a Senior Researcher of CNPq. We thank Mr Benedito Silva and $\mathrm{Mr}$ Paulo Márcio Nunes, students from the Federal University of Maranhão, for technical assistance. We are also indebted to Dr Manoel Barral-Netto for his critical comments.

\section{References}

Abramson, M. A., Dietze, R., Frucht, D. M., Schwantz, R. \& Kenney, R. T. (1995). Comparison of New and Old World leishmanins in an endemic region of Brazil. Clinical Infectious Diseases, 20, 1292-1297.

Ali, A. \& Ashford, R. W. (1993). Visceral leishmaniasis in Ethiopia. I. Cross-sectional leishmanin skin test in an endemic locality. Annals of Tropical Medicine and Parasitology, 87, 157-161.

Araújo, J. A. C., Rebêlo, J. M. M., Carvalho, M. L. \& Barros, V. L. L. (2000). Composição dos flebotomíneos (Diptera, Psychodidae) do municipio de Raposa-MA, Brasil. Area endêmica de leishmanioses. Entomologia y Vectores, 7 , 33-47.

Badaró, R., Jones, T. C., Carvalho, E. M., Pedral-Sampaio, D., Reed, S. G., Barral, A., Teixeira, R. \& Johnson, W. D. Jr (1986a). New perspectives on a subclinical form of visceral leishmaniasis. Fournal of Infectious Diseases, 154 1003-1011.

Badaró, R., Reed, S. G., Barral, A., Orge, G. \& Jones, T. C. (1986b). Evaluation of the micro enzyme-linked immunosorbent assay (ELISA) for antibodies in American visceral leishmaniasis: antigen selection for detection of infection specific responses. American fournal of Tropical Medicine and Hygiene, 35, 72-78.

Badaró, R., Jones, T. C., Lourenço, R., Cerf, B. J., Sampaio, D., Carvalho, E. M., Rocha, H., Teixeira, R. \& Johnson, W. D. Jr (1986c). A prospective study of visceral leishmaniasis in an endemic area of Brazil. Foumal of Infectious Diseases, 154, 639-649.

Carvalho, E. M., Barral, A., Pedral-Sampaio, D., BarralNetto, M., Badaró, R., Rocha, H. \& Johnson, W. D. Jr (1992). Immunological markers of clinical evolution in children recently infected with $L$. donovani chagasi. foumal of Infectious Diseases, 165, 535-540.

Carvalho, E. M., Bacellar, O., Brownell, C., Regis, I., Coffman, R. L. \& Reed, S. G. (1994). Restoration of IFN- $\gamma$ 
production and lymphocyte proliferation in visceral leishmaniasis. Foumal of Immunology, 152, 5949-5956.

Cerf, B. J., Jones, T. C., Sampaio, D., Teixeira, R. \& Johnson, W. D. Jr (1987). Malnutrition as a risk factor for severe visceral leishmaniasis. Foumal of Infectious Diseases, 156, 1030-1033.

Cox, D. R. (1972). Regression models and life tables. fournal of the Royal Statistical Sociery B, 34, 187-220.

Cuba, C. A. C., Marsden, P. D., Barreto, A. C., Jones, T. C. \& Richards, F. (1985). The use of different concentration of leishmanial antigen in the skin testing to evaluate delayed hypersensitivity in American cutaneous leishmaniasis. Revista da Sociedade Brasileira de Medicina Tropical, 18, 231-236.

Dye, C., Vidor, E. \& Dereure, J. (1993). Serological diagnosis of lcishmaniasis: on detceting infection as well as disease. Epidemiology and Infection, 103, 647-656.

Evans, T. G., Vasconcelos, I. A. B., Lima, J. W., Teixeira, J. M., McAullife, I. T., Lopes, U. G., Pearson, R. D. \& Vasconcelos, A. W. (1992). Epidemiology of visceral leishmaniasis in northeast Brazil. Fournal of Infectious Diseases, 166, 1124-1132.

FNS, Fundação Nacional de Saúde (1996). Controle, Diagnóstico e Tratamento de Leishmaniose Visceral (Calazar). Brasília: Ministério da Saúde, Brasil.

Gama, M. E. A., Barbosa, J. S., Pires, B., Cunha, A. K. B. Freitas, A. L., Ribeiro, I. R. \& Costa, J. M. L. (1997). Avaliação do nivel de conhecimento que a população residente em áreas endêmicas periurbana e rural tem sobre leishmaniose visceral, Estado do Maranhão, Brasil. Cadernos de Saúde Pública, 14, 109-118.

Jahn, A., Lelmett, J. L. \& Diesfeld, H. J. (1986). Seroepidemiological study on kala-azar in Baringo District, Kenya Fournal of Tropical Medicine and Hygiene, 89, 91-104.

Lee, J. (1994). Odds ratio or relative risk for cross-sectional data? International fournal of Epidemiology, 23, 201-203.

Lin, D. Y. \& Hei, L. J. (1989). The robust inference for the Cox proportional hazards model. Fournal of the American Statistical Association, 84, 1074-1078.

Pampiglione, S., Manson-Bahr, P. E. C., La Placa, M.,
Borgatti, M. A. \& Musumeci, S. (1975). Studies in Mediterranean leishmaniasis. 3. The leishmanin skin test in kalaazar. Transactions of the Royal Society of Tropical Medicine and Hygiene, 69, 60-68.

Rebêlo, J. M. M., Mendes, W. A., Costa, J. M. L. \& Cavaleiro, N. (1996). Lista preliminar das espécies do gênero Lutzomyia França, 1924 (Psychodidae, Phlebotominae) do Estado do Maranhão, Brasil. Cadernos de Saúde Pública, 12, 545-549.

Reed, S. G., Badaró, R., Mansur, H., Carvalho, E. M., Lourenço, R., Lisboa, A., Teixeira, R., Johnson, W. D. Jr \& Jones, T. C. (1986). Selection of a skin test antigen for American visceral leishmaniasis. American foumal of Tropical Medicine and Hygiene, 35, 79-85.

Silveira, F., Shaw, J. J., Bichara, C. N. C. \& Costa, J. M. L (1997). Leishmaniose visceral americana. In: Doenças Infecciosas e Parasitárias: Enfoque Amazônico, Leão, R. N. C. (coord.), Belém, Cejup: UEPA, 40, 631-644.

Stata Corporation (1997). Stata Reference Manual release 5. Texas: Stata corporation.

Waterlow, J. C. (1972). Classification and definition of protein-calorie malnutrition. British Medical fournal, iii, $566-569$.

Waterlow, J. C., Buzina, R., Keller, W., Lane, J. M., Nichaman, M. Z. \& Tanner, J. M. (1977). The presentation and use of height and weight data for comparing the nutritional status of groups of children under the age of 10 years. Bulletin of the World Health Organization, 55, 489-498.

WHO (1990). Control of Leishmaniasis. Geneva, Switzerland: World Health Organization, Technical Report Series, no. 793.

WHO Working Group (1986). Use and interpretation of anthropometric indicators of nutritional status. Bulletin of the World Health Organization, 64, 924-941.

Received 30 May 2000; revised 4 June 2001; accepted for publication 7 fune 2001

TRANSACTIONS OF THE ROYAL SOCIETY OF TROPICAL MEDICINE AND HYGIENE (2002) 96, 28

\section{Book Review}

Malaria in Sri Lanka: Current Knowledge on Transmission and Control. F. Konradsen, F. P. Amerasinghe, W. van der Hoek \& P. H. Amerasinghe. Colombo: International Water Management Institute, 2000 . xiv $+77 \mathrm{pp}$. Price US $\$ 20.00$ (US $\$ 10.00$ in developing countries). ISBN 92-9090-406-2.

This useful volume sets out to provide a comprehensive account of malaria in Sri Lanka for students, researchers and the malaria-control community in that country. This book can also provide profitable reading for the malariologist whose geographical focus lies elsewhere, as Sri Lanka has a famous history of providing high-quality primary health care (PHC), and thus is an important model of the role that PHC can play in malaria-endemic regions. Sri Lanka is also considered perhaps the prime example of a country that achieved the virtual eradication of malaria in the $1960 \mathrm{~s}$, only to see its resurgence in the latter years of that decade.

The authors of Malaria in Sri Lanka are most comfortable approaching malaria from the vector-control perspective. There is a strong chapter on the biology of Sri Lankan anopheline vectors, and informative discussion, in the 'Malaria control' chapter, of the peculiarities of the ancient Sri Lankan irrigation systems and its 'tanks' as vector breeding sites. Some otherwise obscure work, such as that on evidence for multiple blood feeding by Anopheles culicifacies, is given a mostly deserved airing in stand-alone 'boxes' interspersed throughout the text. My preference would have been for more depth in the area of parasite biology. Further discussion of the development and spread of resistance to chloroquine and sulfadoxine-pyrimethamine as it relates to the specific epidemiology of malaria (vivax and falciparum) on the island would also have been welcome.

In contrast to many familiar African endemic settings where the acquisition of immunity is almost universal, Sri Lanka's malaria patients are very likely to be adults, and asymptomatic infections are rare. The chapter on immunity is thus of general interest to malariologists, and the important contribution of K. N. Mendis and her colleagues is heavily drawn upon. Some of the most important investigations of transmission-blocking immunity, for example, are from Sri Lanka. Whereas both Plasmodium vivax and $P$. falciparum are discussed in the context of particular studies, there is unfortunately no consideration of interactions between these 2 species in Sri Lanka, such as those observed in endemic areas in the Western Pacific.

This slim, readable book will be particularly valuable for students specializing in malaria and disease control, providing in one volume a useful treatment of most aspects of malaria. For researchers and professionals working outside Sri Lanka its main interest lies in the contrast between the island's particular experience of malaria, and that of the other endemic regions in which we work.

Colin Sutherland

Department of Infectious and Tropical Diseases London School of Hygiene and Tropical Medicine

Keppel Street

London WCIE $7 H T, U K$ 